\title{
UKŁAD WYLOTOWY TYPU KOLANA SPRĘŻARKI PROMIENIOWEJ I OSIOWO-PROMIENIOWEJ
}

\begin{abstract}
Kolano jest układem wylotowym kanału przepływowego sprężarki promieniowej i osiowo-odśrodkowej, w którym następuje zmiana kierunku przepływu z promieniowego na kierunek wyznaczony przez oś dyfuzora komory spalania. W pracy przedstawiono metodę wyznaczania parametrów strumienia w przekroju wyjściowym układu wylotowego sprężarki promieniowej i osiowo-odśrodkowej. Analiza obejmuje układ wylotowy typu kolana. Zaprezentowano także odpowiednią metodę określania parametrów geometrycznych dla kanału wylotowego tego typu. Wymienione metody mogą być stosowane w trakcie realizacji projektu koncepcyjnego sprężarki, a oparto je na równaniu zachowania energii, równaniu ciągłości przepływu, pierwszej i drugiej zasadzie termodynamiki oraz funkcjach gazodynamicznych i definicjach używanych w teorii maszyn wirnikowych. Końcowa część pracy zawiera zasady doboru obliczeniowej wartości sprężu sprężarki z promieniowym dyfuzorem łopatkowym oraz wnioski.
\end{abstract}

Słowa kluczowe: sprężarka promieniowa i osiowo-promieniowa, kanał wylotowy, kolano

\section{Nomenklatura}

$a$ - prędkość dźwięku

$b$ - szerokość kanału

$C$ - prędkość bezwzględna

$D$ - średnica

$F$ - pole powierzchni

$h$ - wysokość kanału

$k \quad$ - wykładnik izentropy

$K_{m}$ - współczynnik blokady przekroju

$l$ - praca właściwa/długość

$\dot{m}$ - strumień masy

$M$ - liczba Macha

$n$ - wykładnik politropy

$p$ - ciśnienie statyczne

$R$ - indywidualna stała gazowa/promień

\footnotetext{
1 Autor do korespondencji: Stanisław Antas, Politechnika Rzeszowska im. Ignacego Łukasiewicza, al. Powstańców Warszawy 12, 35-959 Rzeszów, e-mail: santas@ @rz.edu.pl, ORCID: 0000-0001-6241-7061.
} 


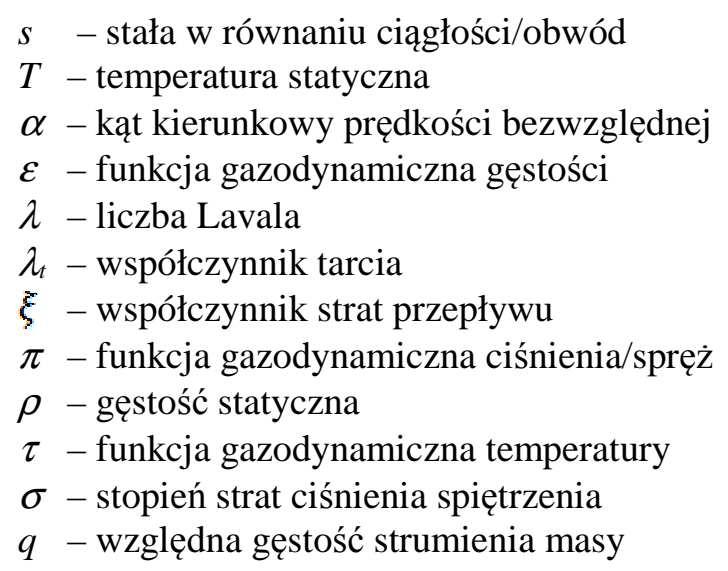

\section{Indeksy}

$/_{A} \quad$ - dotyczy parametru części osiowej sprężarki

$/_{R} \quad$ - dotyczy parametru części promieniowej sprężarki

/s - dotyczy parametru sprężarki

$/_{K S}$ - dotyczy parametru komory spalania

$/ g r \quad$ - dotyczy parametru związanego z granicą pracy statecznej

$/ k r$ - dotyczy parametru krytycznego

lo - dotyczy parametru obliczeniowego

Ir - dotyczy parametru związanego z tarciem

$I_{z r} \quad$ - dotyczy parametru zredukowanego

$/ 1 \ldots 6$ - dotyczy parametru związanego z odpowiednim przekrojem kontrolnym

$\Gamma^{*} \quad$ - dotyczy parametru spiętrzenia

\section{Wprowadzenie}

Układ wylotowy sprężarki odśrodkowej służy do doprowadzenia sprężonego strumienia powietrza do jego odbiornika. Sprężone powietrze jest następnie kierowane dalej do kolejnego zespołu silnika w określonym kierunku. Zadaniem układu wylotowego jednostopniowej lub dwustopniowej sprężarki promieniowej oraz osiowo-odśrodkowej jest zatem zebranie i odpowiednie skierowanie sprężonego czynnika do odbiorników różnych typów konstrukcyjnych. Wykonanie tego zadania powinno przebiegać $\mathrm{w}$ taki sposób, aby praca sprężarki poprzedzającej jej układ wylotowy nie uległa zakłóceniu. W celu zapewnienia prawidłowej pracy sprężarki i odpowiednich osiągów silnika kształty układów wylotowych oraz ich rozwiązania konstrukcyjne winny być odpowiednio starannie dobrane. Należy zauważyć, że w przekroju wyjściowym końcowego dyfuzora sprężarki promieniowej prędkość czynnika zwykle znacznie przekracza wartość dopuszczalną ze względu na prawidłową pracę odbiornika. Układy wylotowe sprężarek pro- 
mieniowych stanowią zatem dyfuzory o różnych kształtach, w których następuje kontynuacja procesu sprężania powietrza kosztem wyhamowania strumienia. $\mathrm{W}$ przypadku lotniczego silnika turbinowego układ ten, łącząc wylot ostatniego dyfuzora sprężarki z dyfuzorem komory spalania, doprowadza powietrze do komory spalania.

Układ wylotowy w postaci dyfuzora stożkowego sprężarki doładowującej silnik tłokowy doprowadza czynnik do przewodów tłoczących, które są rurami o stałym przekroju kierującymi strumień powietrza lub mieszankę paliwowo-powietrzną do poszczególnych cylindrów.

Do najczęściej stosowanych we współczesnych konstrukcjach układów wylotowych sprężarek promieniowych należą:

- dyfuzor typu łącznika,

- osiowy dyfuzor łopatkowy,

- dyfuzor stożkowy,

- dyfuzor typu kolana,

- dyfuzor zakrzywiony.

Ostatni z wymienionych powyżej układów wylotowych jest stosowany wyłącznie $\mathrm{z}$ dyfuzorem rurkowym sprężarki promieniowej lub osiowo-promieniowej $[1,2]$. Należy zauważyć, że istnieje znaczna liczba publikacji dotyczących analizy parametrów czynnika przepływającego przez wlot, wirnik, dyfuzor bezłopatkowy i łopatkowy sprężarki promieniowej. Należy także zaznaczyć, że w dostępnej literaturze przedmiotu brakuje publikacji dotyczących kompleksowej analizy parametrów termicznych, kinematycznych i geometrycznych układów wylotowych sprężarek promieniowych i osiowo-promieniowych.

\section{Kolano wylotowe}

W turbinowych silnikach śmigłowych (np. RR500TP, Allison 250-B17) oraz śmigłowcowych (np. RR300, Allison 250-C30, GTD-350 - rys. 1.) stosuje się kolektory dwustrumieniowe sprężarki promieniowej i osiowo-promieniowej z układem wylotowym w kształcie kolana o stałym lub nieznacznie rosnącym w kierunku przepływu polu przekroju. Kolano kieruje sprężone powietrze do długich, prostych dyfuzorów stożkowych komory spalania, hamujących strumień do prędkości niezbędnych ze względu na prawidłową pracę komory spalania z przepływem zwrotnym $\left(M_{K S}=0,05 \div 0,1\right)[3]$.

Zadanie kolana, stanowiącego kanał zakrzywiony, polega na opóźnieniu i zmianie kierunku przepływu czynnika. Przepływ przez kolana wylotowe jest złożony. Występują tutaj bowiem przepływy wtórne (indukowane, kolanowe) oraz oderwanie strugi związane $\mathrm{z}$ dyfuzorowym ukształtowaniem kolana. Ze względu na brak publikowanych danych, straty ciśnienia spiętrzenia w kolanach określa się na podstawie wyników badań kanałów zakrzywionych o stałym przekroju. 


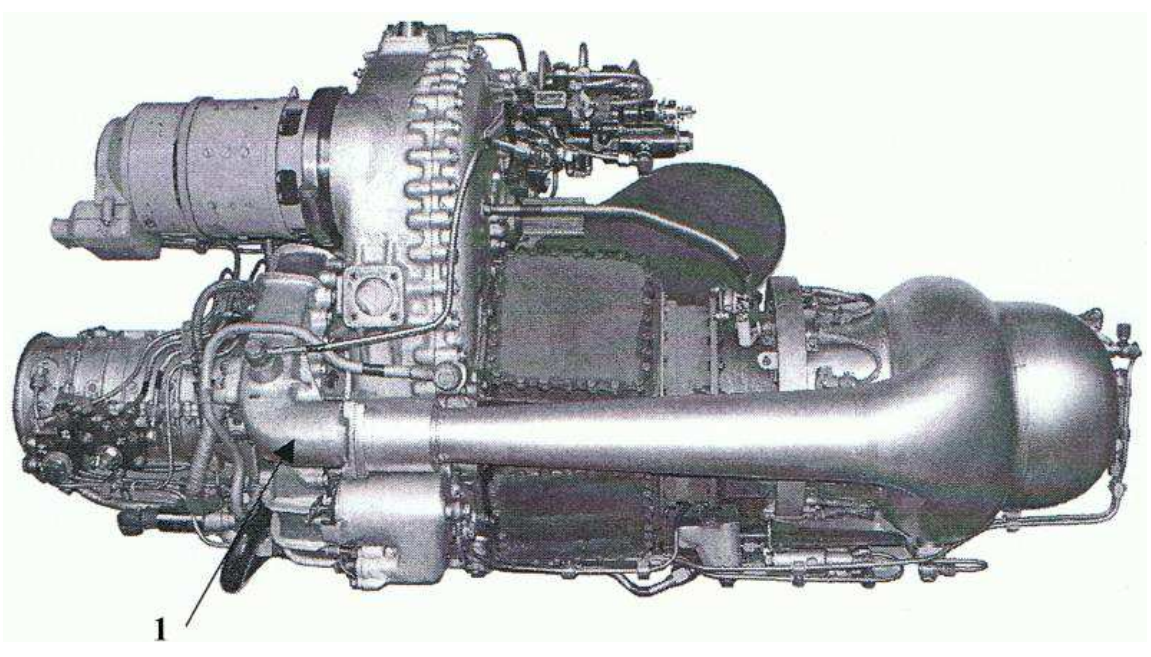

Rys. 1. Silnik śmigłowcowy GTD-350 - przekazany do Politechniki Rzeszowskiej przez WSK PZL Rzeszów: 1 - układ wylotowy sprężarki typu kolana

Jeżeli w kanale przepływowym jest zachowana stała wartość pola powierzchni przekroju, to dla przewodu prostokątnego zagiętego współczynnik strat przepływu jest funkcją parametrów geometrycznych - rys. 2.:

a) kąta zagięcia $\alpha$ kanału,

b) stosunku wymiarów $R / b$ przekroju wzdłużnego,

c) stosunku wymiarów $h / b$ przekroju poprzecznego.

Aby określić straty ciśnienia spiętrzenia $\mathrm{w}$ przewodzie zagiętym, można się posługiwać zależnością:

$$
\Delta p_{5,6}^{*}=\zeta_{5,6} \frac{\rho_{5} C_{5}^{2}}{2}
$$

gdzie $\rho_{5}, C_{5}$ - odpowiednio gęstość i prędkość strumienia w przekroju wejściowym przewodu zagiętego. Natomiast współczynnik strat przepływu w kanale zagiętym wyznacza się z relacji podanej przez G.N. Abramowicza [4]:

$$
\zeta_{5,6}=K_{1} A B C
$$

gdzie: $K_{1}=0,73$ - współczynnik proporcjonalności, $A=f(\alpha)$ - mnożnik zależny od kąta zagięcia przewodu (funkcję ilustruje rys. 2a), $B=f(R / b)-$ mnożnik zależny od kształtu przekroju wzdłużnego (zależność podano na rys. 2b), $C=f(h / b)$ - mnożnik zależny od kształtu przekroju poprzecznego kanału (związek przedstawiono na rys. 2c). 
(a)

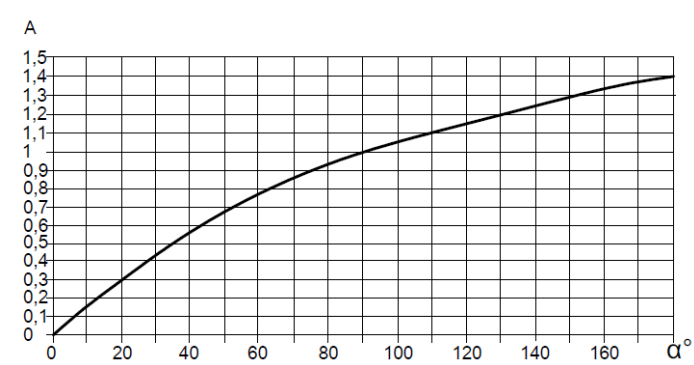

(c)

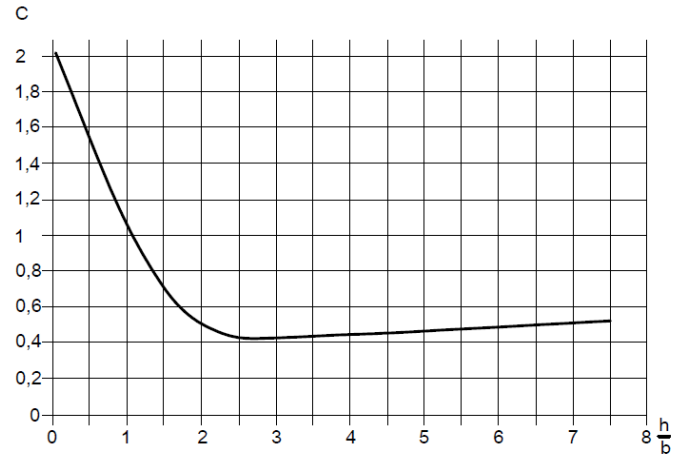

(b)

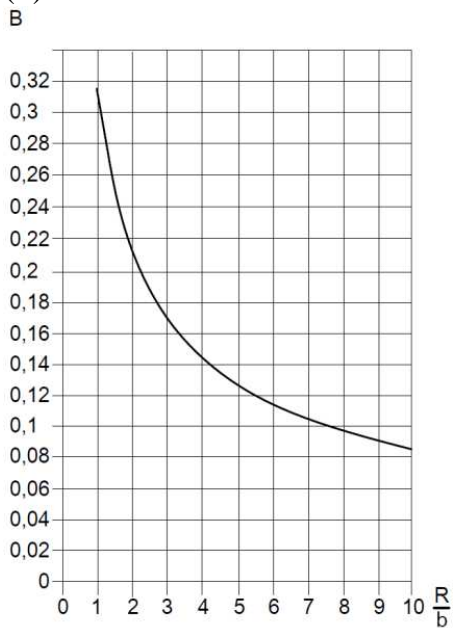

(d)

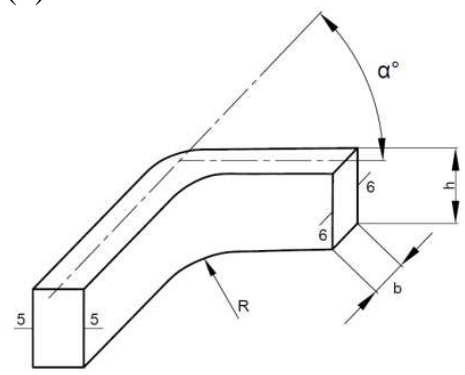

Rys. 2. Składowe współczynnika strat przepływu przewodu zagiętego (a), (b), (c) oraz jego parametry geometryczne (d) [5]

Przekrój wejściowy kolana odpowiada przekrojowi wyjściowemu (5-5) kolektora, zachowując jego kształt, zaś przekrój wyjściowy kolana (6-6) ma zazwyczaj zarys kołowy.

W przypadku kolektorów o zarysie prostokątnym i kwadratowym współczynnik strat przepływu w kolanie określa się na podstawie jego składowych, odczytanych bezpośrednio z rys. 2. Idelczik [6] do stosowania w praktyce zaleca wyznaczanie składowych współczynnika strat przepływu z analogicznych relacji.

Jeśli kształt przekroju wejściowego kolana odbiega od prostokątnego i kwadratowego, wówczas przekrój ten sprowadza się do równoważnego pod względem strat przekroju kwadratowego $(b=h)$. Za przekroje równoważne uważa się te, które mają takie same promienie hydrauliczne [7]: 


$$
r_{h}=\frac{F_{5}}{s_{5}}
$$

gdzie: $F_{5}$ - pole powierzchni przekroju wejściowego kolana, równe przekrojowi kanału kolektora w przekroju wyjściowym, $s_{5}$ - obwód przekroju $F_{5}$.

Zatem:

$$
r_{h}=\frac{h^{2}}{4 h}=\frac{1}{4} h
$$

Z porównania reguł (3) oraz (4) otrzymuje się dla kanału równoważnego:

$$
h=\frac{4 F_{5}}{s_{5}}
$$

Dla określonych parametrów kanału zastępczego $h / b=1,0$ oraz $R / h$, gdzie promień zagięcia przewodu $R$ przyjmuje się z warunków konstrukcyjnych, $\mathrm{z}$ rys. 2. odczytuje się składowe współczynnika strat przepływu w kolanie.

Współczynnik strat przepływu w kolanie wylotowym określa zależność definicyjna [8]:

$$
\zeta_{5,6}=\frac{l_{r 5,6}}{C_{5}^{2} / 2}
$$

gdzie: $l_{r 5,6}$ - praca strat tarcia w kolanie, $C_{5}$ - prędkość strumienia w przekroju wejściowym kolana (wyjściowym kolektora), lub:

$$
\zeta_{5,6}=\frac{\Delta p_{5,6}^{*}}{\rho_{5} C_{5}^{2} / 2}
$$

gdzie spadek ciśnienia spiętrzenia w kolanie:

$$
\Delta p_{5,6}^{*}=p_{5}^{*}-p_{6}^{*}
$$

Znajomość parametrów strumienia w przekroju wejściowym kolana oraz współczynnika strat przepływu $\xi_{5,6}$ pozwala na wyznaczenie parametrów w jego przekroju wyjściowym (6-6). Temperatura spiętrzenia strumienia w przekroju wyjściowym kolana wylotowego (6-6) jest określana z zależności dla przepływu energetycznie odosobnionego:

$$
T_{6}^{*}=T_{5}^{*}
$$


Prędkość krytyczną dźwięku wyznacza formuła:

$$
a_{k r 6}=\sqrt{\frac{2 k R}{k+1} T_{6}^{*}}
$$

Prędkość wypływu strumienia można wyznaczyć z relacji przybliżonej:

$$
C_{6}=C_{5}-\Delta C_{5,6}
$$

gdzie spadek prędkości w kolanie $\Delta C_{5,6}=(0 \div 5) \frac{m}{s}$.

Dla komór spalania indywidualno-pierścieniowych prędkość strumienia powinna zawierać się w przedziale wartości: $C_{6}=90 \div 130 \mathrm{~m} / \mathrm{s}$ [5].

Liczba Lavala prędkości wypływu strumienia z kolana jest obliczana z zależności definicyjnej [9]:

$$
\lambda_{6}=\frac{C_{6}}{a_{k r 6}}
$$

zaś jej wartość powinna mieścić się $\mathrm{w}$ przedziale $\lambda_{5}=0,2 \div 0,3$.

Znajomość wartości liczby Lavala prędkości strumienia w przekroju wyjściowym kolana umożliwia wyznaczenie wartości funkcji gazodynamicznej temperatury [9]:

$$
\tau\left(\lambda_{6}\right)=\left(1-\frac{k-1}{k+1}\right) \lambda_{6}^{2}
$$

oraz temperatury statycznej:

$$
T_{6}=T_{6}^{*} \tau\left(\lambda_{6}\right)
$$

Stopień strat ciśnienia spiętrzenia w kolanie wylotowym określa formuła:

$$
\sigma_{5,6}=1-\frac{k}{k+1} \zeta_{5,6}\left(1-\frac{k-1}{k+1} \lambda_{5}^{2}\right)^{\frac{1}{k-1}} \lambda_{5}^{2}
$$

Ciśnienie spiętrzenia powietrza w przekroju wyjściowym kolana oblicza się ze związku definicyjnego stopnia strat ciśnienia spiętrzenia:

$$
p_{6}^{*}=\sigma_{5,6} p_{5}^{*}
$$


Ciśnienie statyczne strumienia w przekroju wyjściowym kolana wyznacza się ze wzoru:

$$
p_{6}=p_{6}^{*} \pi\left(\lambda_{6}\right)
$$

gdzie funkcję gazodynamiczną ciśnienia określa formuła [9]:

$$
\pi\left(\lambda_{6}\right)=\left(1-\frac{k-1}{k+1} \lambda_{5}^{2}\right)^{\frac{1}{k-1}}
$$

Funkcja gazodynamiczna - względna gęstość strumienia masy jest określona równaniem [9]:

$$
q\left(\lambda_{6}\right)=\lambda_{6}\left(1-\frac{k-1}{k+1} \lambda_{6}^{2}\right)^{\frac{1}{k-1}}\left(\frac{k+1}{2}\right)^{\frac{1}{k-1}}
$$

Pole powierzchni kanału przepływowego w przekroju wyjściowym kolana opisuje relacja:

$$
F_{6}=\frac{\dot{m} \sqrt{T_{6}^{*}}}{s p_{6}^{*} q\left(\lambda_{6}\right) K_{m 6}}
$$

gdzie współczynnik blokady przekroju $K_{m 6}=0,97-0,98$.

Gęstość statyczną powietrza w przekroju wyjściowym łącznika oblicza się $\mathrm{z}$ formuły:

$$
\rho_{6}=\rho_{6}^{*} \varepsilon\left(\lambda_{6}\right)
$$

gdzie gęstość spiętrzenia wyznacza się z równania stanu:

$$
\rho_{6}^{*}=\frac{p_{6}^{*}}{R T_{6}^{*}}
$$

natomiast funkcję gazodynamiczną gęstości określa zależność [9]:

$$
\varepsilon\left(\lambda_{6}\right)=\left(1-\frac{k-1}{k+1} \lambda_{6}^{2}\right)^{\frac{1}{k-1}}
$$


Sprawdzenie poprawności obliczeń może mieć następujący przebieg.

Temperaturę statyczną strumienia w przekroju wyjściowym kolana oblicza się z zależności dla przepływu izoenergetycznego:

$$
T_{6}=T_{5}+\frac{C_{5}^{2}-C_{6}^{2}}{\frac{2 k R}{k-1}}
$$

Wykładnik politropy sprężania w kolanie można wyznaczyć na podstawie równania na pracę tarcia:

$$
\frac{n_{5,6}}{n_{5,6}-1}=\frac{k}{k-1}-\frac{l_{r 5,6}}{R\left(T_{6}-T_{5}\right)}
$$

gdzie pracę sił tarcia podczas przepływu przez kolano określa wzór:

$$
l_{r 5,6}=\zeta_{5,6} \frac{C_{5}^{2}}{2}
$$

Ciśnienie statyczne strumienia w przekroju wyjściowym kolana wyznacza się z równania politropy:

$$
p_{6}=p_{5}\left(\frac{T_{6}}{T_{5}}\right)^{\frac{n_{5,6}}{n_{5,6}-1}}
$$

Ciśnienie spiętrzenia powietrza w przekroju wyjściowym kolana oblicza się, wykorzystując równanie izentropy:

$$
p_{6}^{*}=p_{5}\left(\frac{T_{6}^{*}}{T_{6}}\right)^{\frac{k}{k-1}}
$$

Gęstość statyczną powietrza na wylocie w przekroju wyjściowym wyznacza się z równania stanu:

$$
\rho_{6}=\frac{p_{6}}{R T_{6}}
$$

Pole powierzchni kanału przepływowego w przekroju wyjściowym kolana określa się z równania ciągłości:

$$
F_{6}=\frac{\dot{m}}{C_{6} \rho_{6} K_{m 6}}
$$


Dla kolan wylotowych stopień dyfuzorowości zwykle zawiera się w przedziale:

$$
\bar{F}_{6,5}=\frac{F_{6}}{F_{5}}=1,0 \div 1,05
$$

\section{Uwagi końcowe}

Obliczeniowa wartość sprężu zarówno sprężarki promieniowej, jak i osiowo-promieniowej $\pi_{S o}^{*}$ powinna być większa od wartości sprężu sprężarki $\pi_{S}^{*}$ zadanej w obliczeniach termogazodynamicznych silnika, a odpowiadającej wartości tego parametru na linii współpracy sprężarki i turbiny.

W lotniczym silniku turbinowym sprężarka bezpośrednio współpracuje z zasilanym przez nią całym kanałem przepływowym silnika, stanowiącym układ dławiący (przepustnicę na wylocie ze sprężarki). W układzie silnika wartość sprężu sprężarki $\pi_{S}^{*}$ określa się zwykle podczas prób odbiorczych, mierząc jego wartość na linii współpracy sprężarki z napędzającą sprężarkę turbiną.

Ilościową ocenę odległości linii współpracy S-TS od granicy statecznej pracy sprężarki (rys. 3.) umożliwia zapas statecznej pracy sprężarki, zdefiniowany wyrażeniem [10]:

$$
\Delta K_{S}=\frac{\pi_{S g r}^{*} /\left(\dot{m}_{1 z r}\right)_{g r}-\pi_{S}^{*} / \dot{m}_{1 z r}}{\pi_{S}^{*} / \dot{m}_{1 z r}}
$$

gdzie: $\dot{m}_{1 z r} \mathrm{i}\left(\dot{m}_{1 z r}\right)_{g r}$ - odpowiednio: zredukowany strumień masy powietrza, określony na wlocie do sprężarki w punkcie współpracy i na granicy statecznej pracy przy $n_{S z r}=i d e m$, natomiast: $\pi_{S}^{*}$ i $\pi_{S g r}^{*}$ - odpowiednio: spręż sprężarki na linii współpracy $\mathrm{S}-\mathrm{TS}$ i na granicy statecznej pracy przy $n_{S z r}=i d e m$.

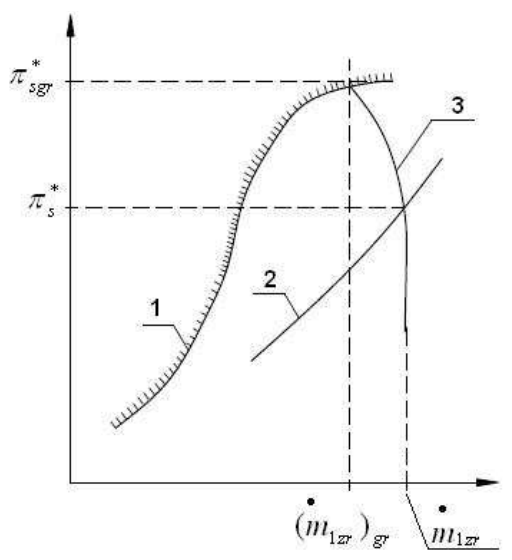

Rys. 3. Ilustracja określenia zapasu statecznej pracy sprężarki: 1 - granica pracy statecznej, 2 - linia współpracy S-TS, 3 - krzywa dławienia $n_{S z r}=i d e m$ 
W zależności od typu konstrukcyjnego sprężarki, sposobu regulacji i zastosowania silnika zapas statecznej pracy wynosi zwykle $\Delta K_{S}=0,1 \div 0,2-$ w przypadku sprężarek promieniowych oraz $\Delta K_{S}=0,15 \div 0,25$ [10] dla osiowych.

Badania eksperymentalne sprężarek promieniowych $\mathrm{z}$ promieniowymi dyfuzorami łopatkowymi wykazały silny wpływ liczby Macha prędkości strumienia w przekroju wejściowym tj. gardzieli dyfuzora łopatkowego $M_{3}$ na przebieg krzywej dławienia sprężarki. Przebieg krzywej dławienia sprężarki promieniowej dla wybranej, obliczeniowej prędkości obrotowej charakteryzuje minimalna wartość strumienia masy powietrza w przekroju wejściowym sprężarki $\left(\dot{m}_{1 \min }\right)=\left(\dot{m}_{1 z r}\right)_{g r}$, odpowiadająca maksymalnej wartości jej sprężu $\pi_{S \max }^{*}=\pi_{S g r}^{*}$ oraz maksymalna wartość strumienia masy powietrza w przekroju wejściowym sprężarki $\dot{m}_{1 \max }=\dot{m}_{1 z r}$ stanowiące odciętą pionowego odcinka charakterystyki, którego rzędna w najwyższym punkcie odpowiada sprężowi $\pi_{S}^{*}$ na linii współpracy S-TS [11].

Zaczerpnięty z pracy [3] rys. 4. ilustruje zależność $\left(\dot{m}_{1 \max }-\dot{m}_{1 \min } / \dot{m}_{1 \text { min }}\right)=f\left(M_{3}\right)$, uzyskaną na podstawie rezultatów badań eksperymentalnych szeregu sprężarek ośrodkowych zawierających promieniowy dyfuzor łopatkowy.

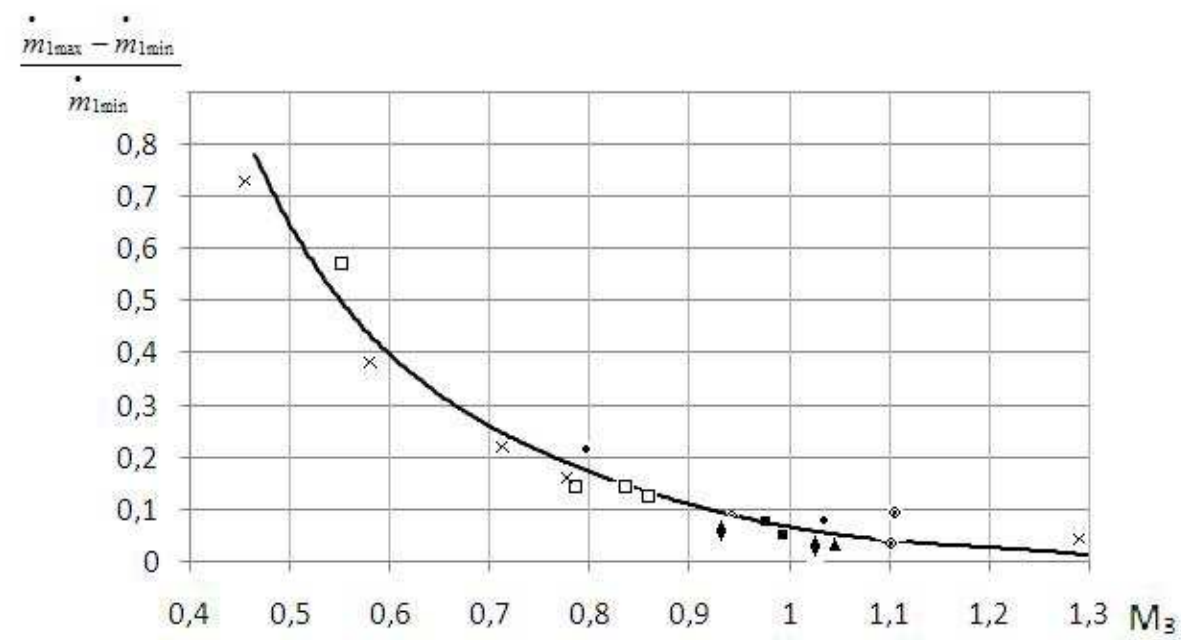

Rys. 4. Zależność ilorazu $\left(\mathrm{m}_{1 \max }-\mathrm{m}_{1 \min }\right) / \mathrm{r}_{1 \min }$ od liczby Macha $M_{3} \mathrm{w}$ przekroju wejściowym dyfuzora łopatkowego

$\mathrm{Z}$ rysunku 4. wynika bezpośrednio, że ze wzrostem liczby Macha $M_{3}$ maleje wartość parametru $\left(\dot{m}_{1 \max }-\dot{m}_{1 \min }\right) / \dot{m}_{1 \min }$, a dla $M_{3}>1,2$ krzywa dławienia przebiega niemal pionowo. Analogiczną zależność typu $\frac{\left(\dot{m}_{1 \max }-\dot{m}_{1 \operatorname{mtn}}\right)}{\dot{m}_{1 \max }}=\mathbf{f}\left(\pi_{S}^{*}\right)$ 
podaje Japikse w pracy [11]. W związku z tym spręż obliczeniowy, na którego wartość projektuje się sprężarkę promieniową, powinien zapewniać jej pracę z zadawalającą wartością zapasu statecznej pracy, zatem $\pi_{S g r}^{*}=\pi_{S o}^{*}$ i relację (31) można także zapisać w następującej postaci:

$$
\Delta K_{S}=\frac{\pi_{S o}^{*} / \dot{m}_{1 \min }-\pi_{S}^{*} / \dot{m}_{1 \max }}{\pi_{S}^{*} / \dot{m}_{1 \max }}
$$

skąd obliczeniowa wartość sprężu sprężarki promieniowej:

$$
\pi_{S o}^{*}=\frac{\left(1+\Delta K_{S}\right) \pi_{S}^{*}}{1+\left(\dot{m}_{1 \max }-\dot{m}_{1 \min }\right) / \dot{m}_{1 \min }}
$$

lub:

$$
\pi_{S o}^{*}=\frac{\left(1+\Delta K_{S}\right) \pi_{S}^{*}}{1+\bar{m}}
$$

gdzie:

$$
\bar{m}=\frac{\dot{m}_{1 \max }-\dot{m}_{1 \min }}{\dot{m}_{1 \min }}
$$

Obliczeniowa wartość sprężu sprężarki promieniowej jest wyznaczana ze wzoru (33) lub (34) po przyjęciu wartości jej zapasu statecznej pracy $\Delta K_{S}$, liczby Macha $M_{3}$ oraz określeniu parametru $\bar{m}$ (rys. 4.). Na wartość liczby Macha $M_{3}$ istotny wpływ wywiera stosunek średnicy wyjściowej $D_{3}$ do wejściowej $D_{2}$ dyfuzora bezłopatkowego. We współczesnych konstrukcjach sprężarek promieniowych lotniczych silników turbinowych stosunek średnic $\frac{D_{3}}{D_{2}}=1,05 \div 1,1$ [12].

Przedstawioną na rysunku 4. zależność można wykorzystać dla doboru odpowiedniej wartości tego stosunku średnic. Według pracy [3], w przypadku $M_{3}<1,2$ dla wyboru stosunku średnic $\frac{D_{3}}{D_{2}}$ odpowiadającego wybranej wartości liczby Macha $M_{3}$, można wykorzystać przybliżoną zależność:

$$
\frac{D_{3}}{D_{2}}=\frac{\bar{M}}{1+a^{\prime}(\bar{M}-1)}
$$


gdzie:

$$
\begin{aligned}
& \bar{M}=\sqrt{\frac{\frac{1}{M_{3}^{2}}+0,2}{\frac{1}{M_{2}^{2}}+0,2}} \\
& a^{\prime}=\frac{\lambda_{t} D_{2}}{8 \operatorname{tg} \alpha_{2} b_{2}}
\end{aligned}
$$

W przedstawionych relacjach oznaczono odpowiednio:

$D_{2}$ - średnica wirnika na wylocie,

$b_{2}$ - szerokość kanału wylotowego wirnika (wysokość łopatek),

$\alpha_{2}$ - kąt kierunkowy prędkości bezwzględnej w przekroju wyjściowym wirnika,

$\lambda_{t}-$ współczynnik tarcia $\left(\lambda_{t}=0,03\right)$,

$M_{2}$ - liczba Macha prędkości bezwzględnej w przekroju wyjściowym wirnika.

Sprężarka osiowo-odśrodkowa jest najkorzystniejszym wariantem dla śmigłowych i śmigłowcowych silników turbinowych o małych strumieniach masy powietrza $\dot{m}=2 \div 6 \mathrm{~kg} / \mathrm{s}$ i umiarkowanych sprężach $6 \leq \pi_{S}^{*} \leq 12$. W sprężarce osiowej dla powyższych wydatków i spręży, łopatki końcowych stopni są zbyt krótkie, co wpływa ujemnie na wartość jej sprawności izentropowej. Szczegółową procedurę rozdziału sprężu sprężarki osiowo-promieniowej $\pi_{S}^{*}$ pomiędzy część osiową $\pi_{S A}^{*}$ i odśrodkową $\pi_{S R}^{*}$ podano w pracy [13]. Ponieważ spręż sprężarki osiowo-ośrodkowej jest iloczynem spręży jej części składowych:

$$
\pi_{S}^{*}=\pi_{S A}^{*} \pi_{S R}^{*}
$$

zatem obliczeniową wartość sprężu sprężarki osiowo-promieniowej określa relacja:

$$
\pi_{S o}^{*}=\left(\pi_{S A}^{*}\right)_{o}\left(\pi_{S R}^{*}\right)_{o}
$$

gdzie obliczeniowa wartość sprężu części osiowej sprężarki jest wyznaczana analogicznie jak dla sprężarki osiowej:

$$
\left(\pi_{S A}^{*}\right)_{o}=\pi_{S A}^{*}\left(1+\frac{\pi_{S A}^{*}}{100}\right)
$$


Obliczeniowa wartość sprężu części promieniowej sprężarki osiowo-odśrodkowej $\left(\pi_{S R}^{*}\right)_{o}$ natomiast, może być obliczana z formuły (33).

Obliczenia układu wylotowego, a zarazem obliczenia przepływowe sprężarki promieniowej lub osiowo-promieniowej można uważać za poprawne, jeśli w rezultacie obliczeń uzyskano rzeczywistą wartość sprężu obliczeniowego sprężarki, definiowanego jako stosunek ciśnienia spiętrzenia w przekroju wyjściowym układu wylotowego $p_{w y l}^{*}$ do ciśnienia spiętrzenia w przekroju wejściowym sprężarki $-p_{1}^{*}$ :

$$
\left(\pi_{S o}^{*}\right)_{r z}=\frac{p_{w y l}^{*}}{p_{1}^{*}}
$$

zbliżoną do wartości teoretycznej - wzór (33) lub (40). Zaleca się, aby błąd względny wartości wymienionych spręży nie przekroczył dla projektu wstępnego $1 \%$ [8], zaś dla projektu koncepcyjnego - 5\% [14].

Jeżeli błąd względny rzeczywistej wartości sprężu obliczeniowego - wzór (42) oraz wartości teoretycznej na początku obliczeń przepływowych sprężarki formuła (33) lub (40) przekracza wartość dopuszczalną, wówczas obliczenia sprężarki należy powtórzyć, przyjmując inną wartość sprawności hydraulicznej mniejszą przy $\left(\pi_{S}^{*}\right)_{o r z}<\pi_{S o}^{*}$ i większą, gdy $\left(\pi_{S o}^{*}\right)_{r z}>\pi_{S o}^{*}$.

\section{Literatura}

1. Antas S., Exhaust system for radial and axial-centrifugal compressor with pipe diffuser, International Journal of Turbo and Jet Engines, 2019, Vol. 36, No 3, s. 297-304.

2. Antas S., Pipe diffuser for radial and axial - centrifugal compressors, International Journal of Turbo and Jet Engines, 2014, Vol. 31, No 1, s. 29-36.

3. Dmitriewskij W.I., Gazodynamiczeskij rasczet i profilirowanie stupieni centrobieżnogo kopriessora, Techniczeskij otczet, No. 137, CIAM, Moskwa 1960.

4. Szlachtenko S.M., Teorija awiacionnych gazoturbinnych dwigatelej, Maszinostrojenie, Moskawa 1975.

5. Gorbunow G.M., Wybor paramietrow i rasczet osnownych kamier sgorania, MAI, Moskwa 1972.

6. Idelczik I.E., Sprawocznik po gidrawliczeskim soprotiwleniam, Maszinostrojenie, Moskwa 1975.

7. Tuliszka E., Sprężarki, dmuchawy i wentylatory, WNT, Warszawa 1976.

8. Biełousow A.N., Musatkin N.F., Radko W.M., Teorija i rasczot awiacionnych łopatocznych maszyn, Samarskij Gosudarstwiennyj Aerokosmiczeskij Institut, Samara 2003.

9. Antas S., Lesikiewicz A., Teoria silników przepływowych. Funkcje gazodynamiczne, Wydawnictwo Politechniki Rzeszowskiej, Rzeszów 1987. 
10. Antas S., Ocena wpływu wybranych metod modyfikacji maszyn wirnikowych turbinowych silników śmigłowych i śmigłowcowych na zapas statecznej pracy sprężarki, Oficyna Wydawnicza Politechniki Rzeszowskiej, Rzeszów 2006.

11. Japikse D., Decisive factors in advanced centrifugal compressor design and development, Concepts ETI, Inc. Wilder, Vermont 2006.

12. Dżygadło Z. [i in.], Zespoły wirnikowe silników turbinowych, Wydawnictwa Komunikacji i Łączności, Warszawa 1982.

13. Antas S., Wolański P., Obliczenia termogazodynamiczne lotniczych silników turbinowych, Wydawnictwa Politechniki Warszawskiej, Warszawa 1989.

14. Dzierżanowski P. [i in.], Konstrukcja silników lotniczych, Wyd. WAT, Warszawa 1972. 
